\section{Australian Journal of \\ Crop Science}

AJCS 14(06):947-952 (2020)

doi: 10.21475/ajcs.20.14.06.p2189

\title{
Sweet corn in no-tillage system on cover crop residues in the Brazilian Cerrado
}

\author{
Kaiê Fillipe Guedes Miranda ${ }^{1}$, José Luiz Rodrigues Torres ${ }^{2^{*}}$, Hamilton Cesar de Oliveira Charlo ${ }^{2}$, Valdeci \\ Orioli Junior ${ }^{2}$, João Henrique de Souza. Favaro ${ }^{3}$, Zigomar Menezes de Souza ${ }^{4}$
}

\author{
${ }^{1}$ Plant Production, Federal Institute of Education, Science and Technology, Triângulo Mineiro (IFTM), Campus \\ Uberaba. St. João Batista Ribeiro, 4000. Zip code 39064-790. Uberaba, Brazil \\ 2IFTM. Campus Uberaba \\ ${ }^{3}$ Agronomy, IFTM (Agrisus Foundation Scientific Initiation Scholarship). Campus Uberaba \\ ${ }^{4}$ University of Campinas (UNICAMP), School of Agricultural Engineering (FEAGRI). Av. Cândido Rondon, 501. Zip \\ code: 13.083-875. Campinas, Brazil
}

\section{*Corresponding author: jlrtorres@iftm.edu.br}

\section{Abstract}

In recent years, the growth of the cultivated area with sweet corn in conventional tillage system in Brazil expanded, although crops can be grown on different residues of cover crops, which improve nutrient cycling and crop productivity. The objective of this study was to evaluate the biomass production and to quantify the rate of plant residues decomposition of different cover crops, and correlate the results with the production and grain yield of sweet corn in an area located in the Cerrado biome. The experimental design used was randomized blocks with eight treatments: PM - pearl millet; SH - sunn hemp; SG - signal grass; PM + SH; PM + SG; $\mathrm{SH}+\mathrm{SG} ; \mathrm{PM}+\mathrm{SH}+\mathrm{SG} ; \mathrm{FW}$ - fallow (spontaneous vegetation), which preceded the cultivation of sweet corn. Fresh biomass (FB) and dry biomass (DB) of the cover crops were evaluated, as well as the rate of plant residue decomposition. Sweet corn productivity, straw and corncob weight, and grain yield were also determined. Pearl millet presented a better performance in FB production, decomposition rate, residue half-life ( $T 1 / 2$ life) in soil, yield, corn cob strawweight and yield of sweet corn. Pearl millet, when mixed with other plants, presented reduced rate of residue decomposition and increased residue $T 1 / 2$ life. The FW presented the lowest biomass production, with great rate of decomposition and low $T 1 / 2$ life. Cover crops grown before sweet corn in soils of good fertility did not affect crop agronomic characteristics. Pearl millet is the best cover crop adapted to Cerrado Brazilian climatic conditions to be used in monoculture or in mixtures with other plants.

Keywords: Zea mays L. saccharata, cover crops, residue decomposition, nutrient cycling.

Abbreviations: FB_fresh biomass; $\mathrm{DB} \_\mathrm{dry}$ biomass; $\mathrm{Mg} \mathrm{ha}^{-1}{ }_{-}$megagram per hectare; $\mathrm{kg} \mathrm{ha}^{-1}{ }_{-}$kilogram per hectare; CEC_capacity to exchange cations (CEC); N_nitrogen; P_phosphor; K_potassium; Ca_calcium; Mg_magnesium; C/N_carbon/nitrogen; k_decomposition constant; T12/2 life_half-life time.

\section{Introduction}

Brazil is the third largest world maize producer (Zea mays L.) (Conab, 2017), and among maize varieties, there is sweet corn (Zea mays L. group saccharata), which is a cereal of special characteristics for human consumption in natura, or processed by the canning industries. In the last record, 36 thousand hectares of sweet corn were grown, and $90 \%$ of the cultivated area is concentrated in the Cerrado biome, with average productivity of about $13 \mathrm{Mg} \mathrm{ha}^{-1}$ (Luz et al., 2014).

Sweet corn grain presents protein, sugar and starch content ranging between 6 to $12 \%, 9$ to $14 \%$ and 30 to $35 \%$, respectively, while common maize has similar protein content, but only about $3 \%$ of sugar and between 60 to $70 \%$ of starch (Araújo et al., 2006). The possibility of continuous sweet corn cultivation throughout the year allows a constant flow of the product to the market, making sweet corn an important horticultural crop (Williams, 2012). In contrast, intense soil cultivation causes significant soil degradation, especially if crops are grown under conventional soil tillage systems.

The implementation of no-tillage sowing system on cover crop plant residues, in areas cultivated with common maize, is a reality for most farmers; however, sweet corn cropping still needs to be better assessed, since sweet corn is an important alternative to contribute to the agroecosystem sustainability (Horvathy Neto et al., 2014). Plant residues left on the soil from cover crops provide physical protection, improve soil fertility and its biological activity, supporting superior yields of the following crops (Carvalho et al., 2011; Assis et al., 2013).

The residues of these plants, after decomposition, increase the availability of nutrients to the following crops. However, in the Cerrado conditions, organic matter mineralization rapidly occurs when compared to regions of temperate climate. This high decomposition rate constrains the 
maintenance of crop residues on Cerrado soils (Sá et al., 2009). Plant species like grasses, sunn hemp and pearl millet are regularly cultivated in the Cerrado regions due to their high biomass production and the ability to improve soil nutrient cycling (Torres et al., 2015; Assis et al., 2017).

The evaluation of nutrient cycling and the accumulation of $\mathrm{N}, \mathrm{P}, \mathrm{K}, \mathrm{Ca}$ and $\mathrm{Mg}$ by cover crops in the Cerrado indicated the accumulation of 131, 215, 13, 19 and $21 \mathrm{~kg} \mathrm{ha}^{-1}$ for signal grass (Urochloa sp.); 118, 11, 59, 43 and $13 \mathrm{~kg} \mathrm{ha}^{-1}$ for sunn hemp, and 165, 219, 23, 41 and $23 \mathrm{~kg} \mathrm{ha}^{-1}$ for pearl millet, respectively (Torres et al. 2008). A significant part of the nutrients evaluated was mineralized in the first 42 days after the deposition of the cover crop residues. This high nutrient cycling has contributed to the maintenance or increase of the yield of common maize (Torres et al., 2008; Bhatt et al., 2012; Assis et al., 2013) and special maize (Kara and Atar, 2013; Pedrotti et al., 2015, Oliveira et al., 2017).

The productivity of common maize for nine consecutive harvests was evaluated by Torres and Pereira (2013) that observed, in most cases, great yield when crop was grown on residues of sunn hemp. However, there still a need for studies to evaluate the cultivation of sweet corn with a focus on no-tillage sown) on residues of cover crops. In this context, the objective of this study was to evaluate the biomass production and to quantify the rate of plant residues decomposition of different cover crops, and correlate with the results with the production and grain yield of sweet corn in area located in the Cerrado biome.

\section{Results and discussion}

\section{Production of green and dry biomass}

The fresh biomass (FB) and dry biomass (DB) of pearl millet and signal grass cultivated alone were greater than the biomasses of sunn hemp or fallow area (Table 1). In the case of cover crops mixtures, where pearl millet was present the $F B$ and DB were significantly higher $(p<0.05)$ when compared to sunn hemp + signal grass biomasses. These results demonstrate the adaptability of these cover crops to the edaphoclimatic conditions of the Cerrado, since both, monocrops (only one cover crop species) and mixtures, produced superior FB and DB when compared to the fallow area (natural Cerrado vegetation).

The values observed (Table 1 ) are in the range of DB production in summer for signal grass, pearl millet and sunn hemp grown in monoculture, which vary from 6 and $13 \mathrm{Mg}$ $\mathrm{ha}^{-1}, 7$ to $12 \mathrm{Mg} \mathrm{ha}^{-1}$ and 4 and $9 \mathrm{Mg} \mathrm{ha}^{-1}$, respectively (Torres et al., 2008, 2015; Carvalho et al., 2011; Assis et al., 2013 and Torres et al., 2017). In winter, these biomasses values decrease to 2 and $3 \mathrm{Mg} \mathrm{ha}{ }^{-1}, 2$ and $4 \mathrm{Mg} \mathrm{ha}^{-1}$, and 3 and $5 \mathrm{Mg} \mathrm{ha}^{-1}$, respectively (Torres et al., 2008; Crusciol and Soratto, 2009). Fallow areas are estimated to produce between 2 and $6 \mathrm{Mg} \mathrm{ha}^{-1}$ at any time of the year (Carvalho et al., 2011).

In general, the high biomass production of the cover crops evaluated can be related to a high volume and better distribution of the rainfalls during the experimental year (Figure 1), which improved DB productions to $11-12 \mathrm{Mg} \mathrm{ha}^{-1}$, a quantity that is suggested as ideal for crop rotation in the Brazilian Cerrado (Sá et al., 2009), a environment that presents high rates of organic matter decomposition.

The DB observed in this study indicates that the plant residues will last for an extended period on soil surface, improving nutrient cycling, primarily $\mathrm{N}$ and $\mathrm{K}$, as evidenced by other studies: Torres et al. (2008), Crusciol and Soratto (2009), Carvalho et al. (2011), Assis et al. (2013), and Alves et al. (2018).

\section{The decomposition of plant residues}

The highest rates of residues decomposition were obtained in the signal grass alone and in the fallow area, leaving, after 150 days, only 40 and $44 \%$ of the plant residues, respectively (Figure 2). 'Pearl millet + signal grass' and pearl millet alone presented about 58 and $56 \%$ of the plant residues, respectively, highlighting that these rates changed according to the cover crops present.

The highest rates of plant residue decomposition were expected to occur where sunn hemp was present. This expectation was due to the sunn hemp plant family, Fabaceae (Leguminosae). These plants are usually low in carbon/nitrogen ratio $(\mathrm{C} / \mathrm{N})$ when compared to the Poaceae plants (grasses). Other studies conducted in the Cerrado with these plant families indicated that pearl millet, a high $\mathrm{C} / \mathrm{N}$ ratio plant, have low rate of residue decomposition (Leite et al., 2010; Torres et al., 2015 and Pacheco et al., 2017). However, this has not happened in the present study, since the highest rates of decomposition occurred where signal grass was cultivated alone or in mixture with sunn hemp.

In other studies carried out in the Cerrado conditions, Torres et al. (2008) and Assis et al. (2013) also observed that residues of signal grass mineralize faster when compared to residues of sunn hemp or pearl millet, suggesting that it is not only the $\mathrm{C} / \mathrm{N}$ ratio of the plant residues that is influencing the process of decomposition.

The influence of rainfall on the rate of plant residues decomposition is evident in the Cerrado conditions. The decomposition rates in the Cerrado increase and decrease in the rainy period, however, low values are observed during the dry periods of the year (Torres et al., 2008; Leite et al., 2010; Carvalho et al., 2011; Pacheco et al., 2017). This influence of water on the rate of plant residues decomposition was also demonstrated in irrigated areas since the results observed in this study were higher when compared to those conducted under natural conditions with the same plants (Torres et al., 2015).

Another important result to be highlighted is that the cover crop pearl millet showed better performance in this study, with good FB and DB production and a low rate of decomposition in monocrops, or in mixtures. Similar results were observed by Torres et al. (2008) and Leite et al. (2010), who also showed that the pearl millet presented low rate of decomposition when compared to sunn hemp. Assis et al. (2017) highlight that pearl millet is a high DB producer, has high $\mathrm{C} / \mathrm{N}$ ratio and a low rate of decomposition in natural conditions of acid soils and little fertility.

\section{Half-life of plant residues}

The decomposition constant $(\mathrm{k})$ of the regression curves (Figure 1) was used to estimated the half-life time of the plant residues, showing that a high rate of decomposition occurred in signal grass alone (Table 2), which presented the lowest half-life time (103 days); pearl millet residues presented the highest half-life alone, or in cover crop mixtures, ranging from 178 to 210 days. Sunn hemp presented an intermediate rate of decomposition, with a 
Table 1. Production of fresh biomass (FB) and dry biomass (DB) of the cover crops preceding the cultivation of sweet corn, in Uberlândia-MG, IFTM, in the agricultural year of 2016/2017.

\begin{tabular}{lcc}
\hline \multirow{2}{*}{ Cover Crop } & FB & DB \\
\hline signal grass (SG) & Mg ha $^{-1}$ & $8,10 \mathrm{c}^{*}$ \\
sunn hemp (SH) & $5,87 \mathrm{~d}$ \\
pearl millet (PM) & $37,63 \mathrm{~b} \mathrm{a}^{*}$ & $8,99 \mathrm{c}$ \\
Fallow (FW) & $50,83 \mathrm{a}$ & $2,48 \mathrm{e}$ \\
SH + SG & $7,20 \mathrm{c}$ & $5,75 \mathrm{~d}$ \\
PM + SG & $39,70 \mathrm{~b}$ & $13,72 \mathrm{a}$ \\
PM + SH & $50,87 \mathrm{a}$ & $9,85 \mathrm{~b}$ \\
PM + SH + SG & $51,07 \mathrm{a}$ & $10,83 \mathrm{~b}$ \\
F & $49,78 \mathrm{a}$ & $36,59 *$ \\
CV (\%) & $24,55^{*}$ & 12,16 \\
\hline
\end{tabular}

* = significative at $p<0,05$. Averages followed by the same letter in column do not differ by Tukey test $(p<0.05)$.

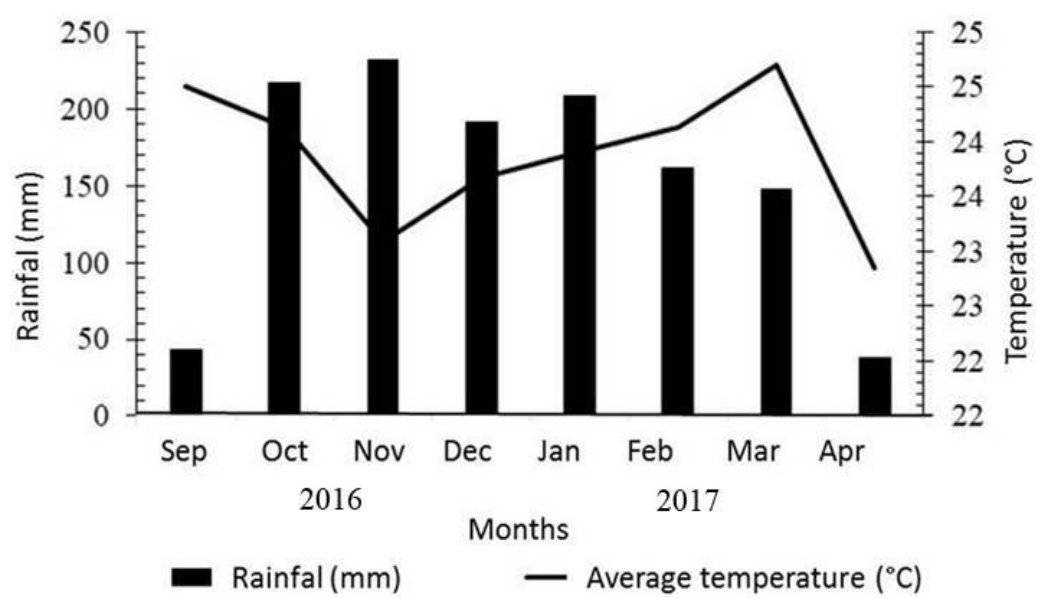

Fig 1. Climatic variables obtained at the meteorological station of the experimental area, in Uberlândia-MG, IFTM, in the agricultural year of 2016/2017.

Table 2. Decomposition constant $(k)$ and half-life time ( $T 1 / 2$ life) of the residues of the coverages used before the cultivation of sweet corn, in Uberlândia-MG, IFTM, in the agricultural year of 2016/2017.

\begin{tabular}{lccc}
\hline & & \multicolumn{2}{c}{ Remaining Dry Biomass } \\
\cline { 2 - 4 } Cover Crop & $\mathrm{k}$ & $\mathrm{T}^{1 / 2}$ life & \multicolumn{1}{c}{$\mathrm{r}^{2}$} \\
\cline { 2 - 4 } & -- & 103 & $0.96^{*}$ \\
\hline signal grass (SG) & 0.0067 & 141 & $0.94^{*}$ \\
sunn hemp (SH) & 0.0049 & 182 & $0.97^{*}$ \\
pearl millet (PM) & 0.0038 & 117 & $0.97^{*}$ \\
Fallow (FW) & 0.0059 & 139 & $0.97^{*}$ \\
SH + SG & 0.0050 & 210 & $0.91^{*}$ \\
PM + SG & 0.0033 & 178 & $0.95^{*}$ \\
PM + SH & 0.0039 & 210 & $0.93^{*}$ \\
PM + SH + SG & 0.0033 & & \\
\hline
\end{tabular}

$*=$ Significative at $5 \%$ by Tukey test $; r^{2}=$ Coefficient of determination.

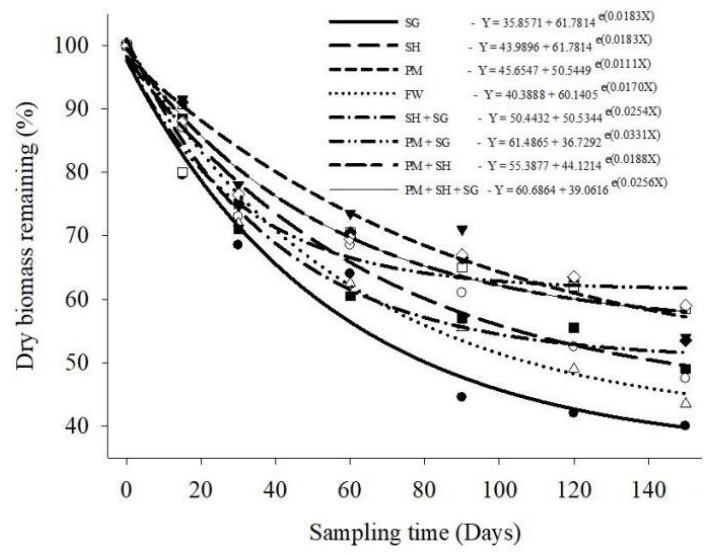

Fig 2. Decomposition of residues of different soil cover crops grown before sweet corn, in Uberlândia-MG, IFTM, in the agricultural year of 2016/2017. 
Table 3. Agronomic characteristics of sweet corn cultivated on residues of different cover crops, in Uberlândia-MG, IFTM, in the agricultural year of 2016/2017.

\begin{tabular}{|c|c|c|c|c|c|c|}
\hline \multirow{3}{*}{ Cover crop } & \multicolumn{6}{|c|}{ Swet corn agronomic aspects } \\
\hline & Straw & Corncob & 100 grains & \multirow{2}{*}{\multicolumn{2}{|c|}{$\begin{array}{c}\text { Productivity } \\
\ldots \ldots \ldots \text { Mg ha }^{-1} \ldots \ldots \ldots .\end{array}$}} & Yield \\
\hline & \multicolumn{3}{|c|}{ 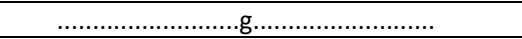 } & & & $\%$ \\
\hline signal grass (SG) & 6.54 & 6.48 & 11.21 & 24.52 & 1.15 & 46.90 \\
\hline sunn hemp (SH) & 5.85 & 5.55 & 9.79 & 21.14 & 0.97 & 46.06 \\
\hline pearl millet (PM) & 6.00 & 5.57 & 10.45 & 22.12 & 0.95 & 45.20 \\
\hline Fallow (FW) & 6.28 & 6.04 & 10.30 & 22.84 & 1.05 & 45.83 \\
\hline $\mathrm{SH}+\mathrm{SG}$ & 6.53 & 6.50 & 10.83 & 24.17 & 1.11 & 46.01 \\
\hline$P M+S G$ & 6.53 & 6.60 & 11.18 & 24.56 & 1.14 & 46.55 \\
\hline $\mathrm{PM}+\mathrm{SH}$ & 6.23 & 6.25 & 10.58 & 23.21 & 1.08 & 46.12 \\
\hline$P M+S H+S G$ & 6.07 & 6.39 & 10.81 & 23.49 & 1.11 & 46.91 \\
\hline $\mathrm{F}$ & $0.34^{\mathrm{ns}}$ & $0.94^{\mathrm{ns}}$ & $037^{\mathrm{ns}}$ & $0.55^{\mathrm{ns}}$ & $0.51^{\mathrm{ns}}$ & $0.43^{\mathrm{ns}}$ \\
\hline CV (\%) & 12.71 & 12.91 & 15.62 & 13.89 & 16.74 & 3.25 \\
\hline
\end{tabular}

${ }^{\mathrm{ns}}=$ Non significative.

days. Kara and Atar (2013) observed that fresh ear yield and yield components of sweet corn decreased with the straw mulch practice in both years of evaluation (2010 and 2011), while the effects of 'sowing date $x$ mulch practice' interactions on emergence rate, fresh ear yield, and yieldrelated traits of sweet corn were significant in 2010 (14.9 Mg $\mathrm{ha}^{-1}$ ) and $2011\left(14.8 \mathrm{Mg} \mathrm{ha}^{-1}\right)$, which were lower than those obtained in this study.

\section{Material and methods}

temperature and humidity in irrigated areas, which induce high soil microbial activity and accelerate the plant residue decomposition rates, as evidenced by Torres et al. (2015), Pacheco et al. (2017) and Collier et al. (2018). In natural conditions, the evaluation of the half-life time of sunn hemp, pearl millet and signal grass residues from the beginning of the rainy season indicated that sunn hemp and pearl millet were the best for residue accumulation on soil (Torres et al., 2008). The signal grass and fallow area were the treatments that showed the lowest half-life time, ranging, respectively, between 52 and 65 days in maize, and between 37 and 47 days in soybean. According to Okumura et al. (2011; 2013), from a nutritional point of view, sweet corn has been more demanding in soil fertility compared to common maize, due to the richness of the sugar, combined with an intense metabolism and a shorter crop cycle. Nitrogen (N) and potassium (K) - which are the nutrients with the highest soil mobility are released more quickly after crop residue decomposition - are highly absorbed by sweet corn, as evidenced by Torres et al. (2008), Pacheco et al. (2017) and Collier et al. (2018).

\section{Production and yield of sweet corn}

There were no significant differences ( $p>0.05)$ among the soil cover crops for all sweet corn variables of production (Table 3), what can be justified by the good conditions of soil fertility of the experimental area commercially used over the past 15 years. This good soil condition conferred high sweet corn yield, which ranged from 21 to $24 \mathrm{Mg} \mathrm{ha}^{-1}$, and was higher than the values observed by Pedrotti et al. (2015). In their study, sweet corn yields were 4.8, 8.5, 0.95 and $1.4 \mathrm{Mg}$ $\mathrm{ha}^{-1}$ on residues of sunn hemp, pigeon pea, bean and peanut, respectively. Parentoni et al. (1990) observed yields ranging from 6 up to $12 \mathrm{Mg} \mathrm{ha}^{-1}$ for the 'BR 401' variety, from 9 to 15 for the 'BR 402' variety, $10 \mathrm{Mg} \mathrm{ha}^{-1}$ for the 'BR 400 ' variety, and $12 \mathrm{Mg} \mathrm{ha}^{-1}$ for 'BR420' and 'BR 421' varieties, with the harvest period ranging between 75 to 98

\section{Location of the experimental area}

The study was conducted at the experimental station of Monsanto, located in the municipality of Uberlândia, Minas Gerais state, Brazil, at $18.938921 \mathrm{~S}$ (latitude) and 48.158996 W (longitude), and $817 \mathrm{~m}$ above sea level, during the 2016/2017 agricultural year. During the summer period of 2015/2016 the area was cultivated with soybean succeeded by the cultivation of wheat during the winter.

\section{The soil of the area}

The soil of the area was classified as Ferralsol (USS Working Group WRB, 2015), clay texture, presenting on the topsoil $(0-0.2 \mathrm{~m}): \mathrm{pH} \mathrm{CaCl} 25.1 ; 46 \mathrm{mg} \mathrm{dm}^{-3}$ of $\mathrm{P}$ (resin); $95 \mathrm{mg} \mathrm{dm}^{-3}$

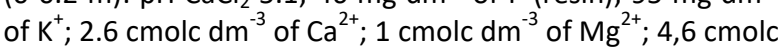
$\mathrm{dm}^{-3}$ of $\mathrm{H}+\mathrm{Al} ; 34.8 \mathrm{~g} \mathrm{dm}^{-3}$ of organic matter; 8.4 cmolc - the final "c" is subscribed $\mathrm{dm}^{-3}$ of cation exchange capacity (CEC) and $46 \%$ of base saturation.

\section{The weather}

The predominant climate of the region is the Aw type, defined as humid tropical with a rainy summer and dry in the winter, according to the classification of Koppen (1948). The average annual rainfall is $1,479 \mathrm{~mm}$, with annual average air temperature of approximately $21.5{ }^{\circ} \mathrm{C}$. During the months of cultivation of the cover crops (06/09/2016) and the sweet corn (24/04/2017) the recorded cumulative rainfall was $1,237 \mathrm{~mm}$. The rainfall recorded during the cultivation of the cover crops and sweet corn was 591 and $395 \mathrm{~mm}$, respectively (Figure 1).

\section{Experimental design}

The experimental design was set in randomized blocks, and treatments were established by different cover crop species in monoculture (monocrop) and in mixtures of species: 1 pearl millet [Pennisetum glaucum (L.) R. Brown] (PM); 2 - 
sunn hemp [Crotalaria juncea (L.)], (SH); 3 - signal grass [Urochloa ruziziensis (R. Germ and Evrard), (SG); 4 - pearl millet + sunn hemp $(\mathrm{PM}+\mathrm{SH}) ; 5$ - pearl millet + signal grass $(\mathrm{PM}+\mathrm{SG}) ; 6$ - sunn hemp + signal grass $(\mathrm{SH}+\mathrm{SG}) ; 7$ - pearl millet + sunn hemp + signal grass $(P M+S H+S G)$, and 8 Fallow (FW) (Natural vegetation with predominance of Poaceae family), all with 4 repetitions.

\section{Cover crops}

The cover crops were grown in the period from October to December 2016. They were sown with no-tillage seeder (eight rows), spaced $0.35 \mathrm{~m}$, and the experimental unit area was $14 \mathrm{~m}^{2}(5 \times 2.8 \mathrm{~m})$, and the useful area for data collecting was the middle of the four (4) central planting rows $\left(2 \mathrm{~m}^{2}\right)$. It was used 30,6 and $30 \mathrm{~kg} \mathrm{ha}^{-1}$ of seeds of pearl millet (PM), sunn hemp (SH) and signal grass (SG), while in the $P M+S H$, $\mathrm{PM}+\mathrm{SG}, \mathrm{SH}+\mathrm{SG}$ and $\mathrm{PM}+\mathrm{SH}+\mathrm{SGB}$ consortia the mixture ratio of $15+3,15+15,3+15$ and $15+6+15 \mathrm{~kg} \mathrm{ha}^{-1}$ of each seed, respectively.

\section{Evaluations}

\section{Production of green and dry biomass}

At $50 \%$ full flowering cover crops were desiccated with glyphosate + 2.4-D dimethylamine salt, at $2 \mathrm{~kg} \mathrm{ha}^{-1}$ and $2 \mathrm{~L}$ $\mathrm{ha}^{-1}$ doses, respectively. Before cover crop dissection, the areas were sampled (central $2 \mathrm{~m}^{2}$ of each parcel), for fresh biomass (FB) determination. Plants were then taken to dry at $65^{\circ} \mathrm{C}$ for 72 hours, for dry biomass (DB) determination (kg $\mathrm{ha}^{-1}$ ).

\section{Decomposition of the plant residues}

To assess the rate of residue decomposition the method of decomposition bags, developed by Santos and Whilford (1981) was used. The nylon bags with $2 \mathrm{~mm}$ aperture and $0.04 \mathrm{~m}^{2}$ size $(0.2 \times 0.2 \mathrm{~m})$ were filed with $20 \mathrm{~g}$ of dry cover crop biomass. In each plot, 12 bags were distributed on the soil surface ( 48 bags per treatment), being collected two bags per plot at each sampling time, which occurred at 15 , 30, 60, 90, 120 and 150 days after the distribution of the bags. After sampling, the plant residue remaining in each bag were sieved and dried at $65{ }^{\circ} \mathrm{C}$ for 72 hours to determine its mass $\left(\mathrm{Mg} \mathrm{ha}^{-1}\right)$.

To describe the decomposition of the plant residues, the exponential mathematical model described by Thomas and Asakawa (1993) was applied $X=X o e^{-k t}$, where, $X$ is the quantity of dry biomass remaining after a period of time $(t)$ in days; Xo is the initial amount of dry biomass; $k$ is the constant of the residue decomposition.

Using the $k$ value of the decomposition equation, the halflife $\left(T^{1 / 2}\right.$ life) of residues remained was calculated using the formula $\mathrm{T}^{1 / 2}$ life $=0.693 / \mathrm{k}$, proposed by Paul and Clark (1996), which expresses the period of time required for half of the cover crop residues to decompose. Mathematical equations were applied using the SigmaPlot Software, Version 10.

The sweet corn hybrid 'SV9298SN' was recommended for the region, which is a hybrid resistant to Spodoptera frugiperda, Helicoverpa zea, Diatrea saccharalis and Elasmopalpus lignosellus, considered the main pest insects for maize crop, and presents short cycle, between 90 and 105 days.
The sowing of sweet corn was carried out in the opposite direction of the cover crop sown, in January 2017, shortly after cover crop desiccation, by placing 3 seeds per meter of the furrow to a depth of $3 \mathrm{~cm}$, at $0.5 \mathrm{~m}$ between rows, for a population of 60,000 plants $\mathrm{ha}^{-1}$. A total of ten lines of sweet corn were sown ( $2.8 \mathrm{~m}$ in length), the useful area considered was the four (4) central lines.

The mineral fertilization used in sweet corn was defined according to soil chemical characteristics and the recommendations were proposed by Sousa and Lobato (2004): $400 \mathrm{~kg} \mathrm{ha}^{-1}$ of 08-28-16 at sown, $400 \mathrm{~kg} \mathrm{ha}^{-1}$ of 20-0020 in the first topdressing fertilization (14 days after sowing), $200 \mathrm{~kg} \mathrm{ha}^{-1}$ of urea $(45 \% \mathrm{~N})$ in the second topdressing fertilization ( 28 days after sowing), to achieve the maximum productive potential of the sweet corn hybrid. The fertilizer application was performed with a mechanical cultivator.

Thirty days after the dissection of the cover crops, a sprinkler irrigation system was installed in the sweet corn crop area. The irrigation management was determined by an interaction of factors (availability of total water by means of conventional tensiometry), climate (reference evapotranspiration) and phenological stage of culture (crop evapotranspiration), aiming to restore the daily sweet corn evapotranspiration, favoring the maximum expression of its productive potential.

\section{Yield of sweet corn and grain yield}

Ninety days after sowing, sweet corn crop was harvested manually, at the moment that the grains had an average $73 \%$ humidity. After harvest and selection of corncobs, the grains were threshed, and crop yield estimated. Productivity was obtained from the corncob's weight (with straw) of the four central lines, and the values extrapolated to $\mathrm{Mg} \mathrm{ha}^{-1}$. The straw and corncob masses were measured and subsequently expressed in $\mathrm{Mg} \mathrm{ha}{ }^{-1}$. The grain yield was obtained after processing of corncob to determine the useful amount of grain in $\mathrm{Mg} \mathrm{ha}{ }^{-1}$ and yield percentage (\%).

\section{Statistical analysis}

The data was initially tested for the ANOVA presumptions ( $p>0.01$ ). The normality of residue distribution (Shapiro-Wilk test) and the homogeneity of variance (Bartlett test) were tested prior to ANOVA ( $F$ test). When significant differences were observed $(p<0.05)$, the means were separated by the Tukey test $(p<0.05)$.

\section{Acknowledgments}

The authors are thankful to Monsanto and to the Federal Institute of Education, Science and Technology, Triângulo Mineiro, Campus Uberaba, for conceding infrastructure to the conduction of the experiments; to the Foundation Agrisus for financing the project; to the National Council for Scientific and Technological Development (CNPq) and the Foundation to Research of Minas Gerais (Fapemig), for granting scholarships to the students that participated in the project.

\section{Conclusion}

Pearl millet alone presented the highest production of fresh mass, with a low rate of residue decomposition and extended half-life time of the residues on the soil. 
When mixed with other plants, pearl millet presented decreased decomposition rate and increased half-life of the combined cover crop residues.

The Cerrado fallow area was the worst coverage evaluated for fresh and dry biomass production, with great rate of decomposition and low half-life time of the plant residues.

Cover crops grown before sweet corn did not affect its agronomic characteristics.

Pearl millet wass the best cover crop adapted to Brazilian Cerrado climatic conditions, sown alone or in mixtures with other cover crops.

\section{References}

Alves VN, Torres JLR, Lana RMQ, Pinheiro MHO (2018) Nutrient cycling between soil and leaf litter in the Cerrado (Brazilian savanna) on eutrophic and dystrophic Neosols. Ac Bot Br. 32: 169-179.

Araújo EF, Araujo RF, Sofiatti V, Silva RF (2006) Maturação de sementes de milho-doce grupo superdoce. Rev Br Sem. 28: 69-76.

Assis RL, Oliveira CAO, Perin A; Simon GA, Souza Junior BA (2013) Produção de biomassa, acúmulo de nitrogênio por plantas de cobertura e efeito na produtividade do milho safrinha. Enc Bio. 9: 1769-1775.

Assis RI, Freitas Rs, Mason Sc (2017) pearl millet production practices in Brazil: a review. Exp Agr. 53: 1-20.

Bhatt OS, Yakadri M, Sivalakshmi Y (2012) Influence of varying plant densities and nitrogen levels on yield attributes and yield of sweet corn. Int J Bio-Res and Str Man. 3: 169-172.

Carvalho AM, Souza LLP, Guimarães Júnior R, Alves PCAC, Vivaldi $L J$ (2011) Cover plants with potential use for croplivestock integrated systems in the Cerrado region. P Agr Br. 46: 1200-1205.

Collier LS, Arruda EM, Campos LFC, Nunes JNV (2018) Soil chemical attributes and corn productivity grown on legume stubble in agroforestry systems. Caat. 31: 279-289.

Conab - Companhia Nacional de Abastecimento (2017) Acompanhamento da safra brasileira de grãos: safra 2008/09, 2012/2013, 2015/16, 2016/2017: Disponível em: http://www.conab.gov.br/ Conabweb/download/pdf. Access on: November 12st, 2017.

Crusciol CAC, Soratto RP (2009) Nitrogen supply for cover crops and effects on peanut grown in succession under a no-till system. Agr Jour. 101:40-46.

Horvathy Neto A, Silva AG, Teixeira IR, Costa KAP, Assis RL (2014) Consórcio de sorgo granífero e braquiária na safrinha para produção de grãos e forragem. Caat. 27: 132141.

IUSS Working Group (2015). World Reference Base for Soil Resources 2014, Update 2015 International Soil Classification System for Naming Soils and Creating Legends for Soil Maps. World Soil Resources Report No. 106. Rome: FAO.

Kara B, Atar B (2013) Effects of mulch practices on fresh ear yield and yield components of sweet corn. Tur J Ag For. 37: 281-287.

Koppen W (1948) Climatologia: con un estudio de los climas de la tierra. Fondo de Cultura Econômica. México, 479 p.

Leite LFC, Freitas RCA, Sagrilo E, Galvão SRS (2010) Decomposição e liberação de nutrientes de resíduos vegetais depositados sobre Latossolo Amarelo no Cerrado Maranhense. Rev Ci Agr. 41:29- 35.

Luz JMQ, Camilo JS, Barbieri VHB, Rangel RM, Oliveira RC (2014) Produtividade de genótipos de milho doce e milho verde em função de intervalos de colheita. Hort $\mathrm{Br} .32$ : 163-167.

Okumura RS, Takahashi HW, Santos DGC, Lobato AKS, Mariano DC, Marques OJ, Silva MHL, Oliveira Neto CF, Lima Junior JA (2011) Influence of diferente nitrogen levels on growth and production parameters in maize plants. J Foo, Agr and Env. 9: 510-514.

Okumura RS, Mariano DC, Franco AAN, Zaccheo PVC, Zorzenoni TO (2013) Sweet corn: Genetic aspects, agronomic and nutritional traits. App Res and Agr. 6: 05114.

Oliveira FCC, Pedrotti A, Felix AGS, Souza JLS, Holanda FSR, Mello Junior AV (2017) Características químicas de um Argissolo e a produção de milho verde nos Tabuleiros Costeiros sergipanos. Agr. 12: 354-360.

Pacheco LP, Miguel ASDCS, Silva RG, Souza ED, Petter FA, Kappes C (2017) Biomass yield in production systems of soybean sown in succession to annual crops and cover crops. P Agr Br. 52: 582-591.

Parentoni SN, Gama EEG, Magnavaca R, Reifschneider FB, Boas GLV (1990) Milho doce. Inf Agr. 14: 17-22.

Paul EA, Clark FE (1996) Dynamics of residue decomposition and soil organic matter turnover. In: Paul EA, Clark FE (Eds). Soil microbiology and biochemistry. Acad. p.158179.

Pedrotti A, Silva TO, Araújo EM, Araújo Filho RN, Holanda FSR (2015) Atributos químicos do solo modificados por diferentes sistemas de cultivo associados a culturas antecessoras ao cultivo do milho, nos Tabuleiros Costeiros. Mag. 27: 292-305.

Sá JCM, Lal R, Dick WA, Piccolo MC, Feigl BE (2009) Soil organic carbon and fertility interactions affected by a tillage chronosequence in a Brazilian Oxisol. S Til Res. 104: 56-64.

Santos PF, Whilford WG (1981) The effects of microarthropods on litter decomposition in a chihuazhuan ecosystem. Ecol. 62:654-669.

Sousa DMG, Lobato E (2004) Cerrado: correção do solo e adubação. 2 ed. Brasília: Embrapa Cerrados, 416 p.

Thomas RJ, Asakawa NM (1993) Decomposition of leaf litter from tropical forage grasses and legumes. S Bi Bio. 25: 1351-1361.

Torres JLR, Pereira MG, Fabian AJ (2008) Produção de fitomassa por plantas de cobertura e mineralização de seus resíduos em plantio direto. P Agr Br. 43: 421-428.

Torres JLR, Pereira MG (2013) Dificuldades e soluções da semeadura direta no Cerrado. Gr. 1: 61-63.

Torres JLR, Araujo AS, Barreto AC, Silva Neto OF, Silva VR; Vieira DMS (2015) Desenvolvimento e produtividade da couve-flor e repolho influenciados por tipos de cobertura do solo. Hort Br. 33: 510-514.

Torres JLR, Gomes, FRC, Barreto, AC, Tamburús AY, Vieira, DMS, Souza ZM, Mazetto Júnior JC (2017) Application of different cover crops and mineral fertilizer doses for no-till cultivation of broccoli, cauliflower and cabbage. Aust Jour Cr Sci. 11:1339-1345.

Williams, MM (2012) Agronomics and economics of plant population density on processing sweet corn. $\mathrm{Fi} \mathrm{Cr}$ Res. 128: 55-61. 